\title{
EFFICACY EMS AND DES ON MUTAGENESIS AND SEEDLING CHARACTERS OF ELEUSINE CORACANA L. GAERTN
}

\section{MULLAINATHAN*, K. AVIYA}

Department of Botany, Annamalai University, Annamalai Nagar 608002, Tamil Nadu, India

\begin{abstract}
This study was performed by exposing the seeds of Finger millet (Eleusine coracana L. Gaertn.) Var CO-13 to Ethyl Methane Sulphonate (EMS) and Diethyl sulphate (DES). The observations were made on seed germination and survivability in $\mathrm{M}_{1}$ generation. The study revealed that germination percentage and survivability were decreased by increasing concentration of the mutagens when compared to the control. The $\mathrm{LD}_{50}$ value was found in $30 \mathrm{mmol}$ of EMS and 40 mmol of DES. So it was found that both mutagens at lower treatments have influenced less biological damage and could be suitable for inducing desirable mutations in Finger millet.
\end{abstract}

Keywords: EMS, DES, LD50 value, Finger millet, Seed germination, Survivability

\section{INTRODUCTION}

Finger millet (Eleusine coracana L. Gaertn.) is an important millet species used as a staple food in many parts of the world. Finger millet is commonly known as 'Ragi' is one of the important food crops and largely grown in Southern States of India [1].

Now a day, out of the many available ways of inducing genetic variability available to the plant breeder, Mutation breeding is of prime importance $[2,3]$. In this technique, the chance of changing specific characters is there, and the meantime, the remaining traits will be stay unaltered [4]. Mutation breeding has been used to create genetic variability in quantitative traits of various crop plants within the shortest possible times [5-7]. Diethyl sulphate is reported to be a monofunctional and strong alkylating agent which ethylates DNA [8].

For any mutagenesis, the main step is to fix the dosage and determining the $\mathrm{LD}_{50}$. The mutagen dose administrated should be sufficient to kill about 50 percent of the seed to obtain the maximum number of mutation [9, 10]. Generally, it was observed, higher doses/concentrations of mutagens produce biological damage to germination and failure to survival at maturity. These biological damages are considered as the indication of mutagenic effect [11]. On the light of above facts, the present investigation was carried out to evaluate the effect of chemical mutagens (EMS and DES) on seed germination and survivability of Finger millet. These parameters are helpful in determining the effect of mutagens for further mutation breeding

\section{programme.}

\section{MATERIALS AND METHODS}

\section{Plant material}

Dry and healthy seeds of Finger millet (Eleusine coracana L. Gaertn.) Var CO-13, were obtained from Tamilnadu Agricultural Research Institute Villupuram.

\section{Mutagens employed}

Chemical mutagens namely, Ethyl methanesulphonate (EMS) $(10,20,30,40$ and $50 \mathrm{mmol})$ and Diethyl sulfate (DES) (20, $30,40,50$ and 60 ) were used at various concentrations. The treatments were done as explained previously [12].

\section{Raising of $M_{1}$ generation}

The treated seeds were sown in seed beds and watered at least once a day. After 25-30 d, seedlings (at 4-5 leaf stage) were shifted to main field in randomized block design with three replications. All the mutagenic treatments including the control were raised adopting a space $30 \times 15 \mathrm{~cm}$ Botanical Garden, Department of Botany, Annamalai University. All the necessary practices like cultural operations and irrigations were carried out.

\section{Seed germination (\%)}

In the laboratory, the seeds of each treatment along with control were placed on absorbent cotton-wet Petri dishes. For each treatment three replicates were studied and the number of seeds germinated on the 7 th day was counted and the germination percentage was calculated.

\footnotetext{
Received 28 February 2018; Accepted 20 May 2018

*Corresponding Author

L. Mullainathan

Department of Botany, Annamalai University, Annamalai Nagar 608 oo2, Tamil Nadu, India

Email: vishnumullai@gmail.com
}

( This article is open access and licensed under the terms of the Creative Commons Attribution License (http://creativecommons.org/licenses/by/4.o/) which permits unrestricted, use, distribution and reproduction in any medium, or format for any purpose, even commercially provided the work is properly cited. Attribution - You must give appropriate credit, provide a link to the license, and indicate if changes were made. 


\section{Plant survival on $3^{\text {th }}$ day}

The number of plants survived on $30^{\text {th }}$ day after sowing was counted from each treatment and the survival percentage was calculated.

\section{RESULTS AND DISCUSSION}

\section{Seed germination (\%)}

The seed germination data on Finger millet (Eleusine coracana L. Gaertn.) Var Co 13 are given in table 1 and table 2. The seed germination percentage of various mutagenic treatments under laboratory conditions revealed that, the germination percentage was decreased with increasing concentrations of EMS and DES. The percentage of seed germination was highest in lower concentration of EMS (10 mmol--84.00\%) and DES (20Mm 86.32\%). Based on the seed germination percentage on the 7 th day, the $\mathrm{LD}_{50}$ values were fixed at 30 mmol for EMS and $40 \mathrm{mmol}$ for DES.

Reduction in seed germination may be due to the effect of mutagen on meristematic tissues of the radical/plumule [13]. One of the physiological effects caused by treatment of these mutagens particularly chemical mutagens might be due to the disturbances in the formation of enzymes involved in the germination process [14]. Similar inhibitory effect on seed germination by the various mutagenic treatments were reported earlier in Onion [15].

\section{Plant survival on 30 th day}

In general, a gradual reduction in the seedling survival in all mutagenic treatments is shown in Table3. The maximum plant survival was recorded at $10 \mathrm{mmol}$ of (72.10\%)in EMS and $20 \mathrm{mmol}$ (73.19\%)in DES. If the higher dose was imposed, growth reduction will be the result in plants [9]. The reduction in plant survival due to the mutagenic treatments has also been reported in Dianthus [16], Horsegram [17] and Ashwagandha [18], Pearl Millet [19], Sesame [20] and Okra [21].

\section{CONCLUSION}

The Finger millet Seed germination and survivability were decreased by increasing concentrations of EMS and DES. It can be concluded that, EMS and DES could be utilized as a potential tool for inducing genetic variability. And among the $30 \mathrm{mmol}$ in EMS and $40 \mathrm{mmol}$ in DES were founded as a threshold dose.

\section{ACKNOWLEDGEMENT}

The facilities provided by Department of Botany, Annamalai University are gratefully acknowledged.

Table 1: Determination of $\mathrm{LD}_{50}$ for EMS on finger millet

\begin{tabular}{llll}
\hline Mutagens & Treatments Conc. (mM) & Seed Germination Percentage (\%) & Percent of reduction over control \\
\hline Control & & 96 & 00.00 \\
& $10 \mathrm{mmol}$ & 86 & 10.41 \\
EMS & 77 & 19.79 \\
& $20 \mathrm{mmol}$ & 51 & 46.87 \\
& $30 \mathrm{mmol}$ & 40 & 58.33 \\
& $40 \mathrm{mmol}$ & 34 & 64.58 \\
\hline
\end{tabular}

Table 2: Determination of $\mathrm{LD}_{50}$ for $\mathrm{DES}$ on finger millet

\begin{tabular}{llll}
\hline Mutagens & $\begin{array}{l}\text { Treatments Conc. } \\
(\mathbf{m M})\end{array}$ & $\begin{array}{l}\text { Seed germination } \\
\text { percentage (\%) }\end{array}$ & Percent of reduction over control \\
\hline Control & & 96 & 00.00 \\
& $20 \mathrm{mmol}$ & 84 & 12.5 \\
DES & 73 & 23.95 \\
& $30 \mathrm{mmol}$ & 52 & 45.83 \\
& $40 \mathrm{mmol}$ & 39 & 59.37 \\
& $50 \mathrm{mmol}$ & 30 & 68.75 \\
\hline
\end{tabular}

Table 3: Effect of mutagens on plant survival (\%) in $M_{1}$ generation ( $30^{\text {th }}$ day) finger millet

\begin{tabular}{llll}
\hline Mutagens & Treatments Conc. (mM) & Range & mean \pm SE \\
\hline Control & & $83.10-87.15$ & $\mathbf{8 1 . 1 6} \pm \mathbf{3 . 9 3}$ \\
EMS & $10 \mathrm{mmol}$ & $72.44-79.18$ & $72.10 \pm 3.51$ \\
& $20 \mathrm{mmol}$ & $64.00-71.51$ & $59.22 \pm 2.91$ \\
& $30 \mathrm{mmol}$ & $49.14-57.13$ & $42.43 \pm 2.47$ \\
& $40 \mathrm{mmol}$ & $31.28-36.11$ & $33.31 \pm 1.27$ \\
& $50 \mathrm{mmol}$ & $19.21-24.85$ & $21.72 \pm 0.89$ \\
& $20 \mathrm{mmol}$ & $73.42-89.31$ & $73.19 \pm 3 \cdot 55$ \\
DES & $30 \mathrm{mmol}$ & $62.54-74.04$ & $64.18 \pm 3.14$ \\
& $40 \mathrm{mmol}$ & $52.08-61.95$ & $44.55 \pm 2.58$ \\
& $50 \mathrm{mmol}$ & $41.84-32.77$ & $35.33 \pm 1.22$ \\
& $60 \mathrm{mmol}$ & $29.12-31.93$ & $24.16 \pm 0.93$ \\
\hline
\end{tabular}




\section{REFERENCES}

1. Joshi PK, Gulati A, Birthal PS, Tewari L. Agriculture diversification in South Asia: patterns, determinants and policy implications. Economic and political weekly. 2004 Jun 12:2457-67.

2. Mei, S., Wu, Y., Zhang, Y., Liu, B. M., Jiang, J. Y. and $\mathrm{Yu}, \mathrm{Z}$. L. 2007. Mutation of rice (Oryza sativa L.) LOX-1/2 near-isogenic lines with ion beam implantation and study of their storability. Nuc. Inst. Meth. Physics Res. Sec. B: Beam Interac. Mat. Atoms. 265:495-500.

3. Mohamad, O., Mohd Nazir, B., Alias, I., Azlan, S., Abdul Rahim, H., Abdullah, M. Z., Othman, O., Hadzim, K., Saad, A., Habibuddin, H. and Golam, F. 2006. Development of improved rice varieties through the use of induced mutations in Malaysia. Plant Mut. Rep. 1:27-34.

4. Aruna, J., Prakash, M. and Sunil Kumar, B. 2010. Studies on effect of physical and chemical mutagens on seedling characters in Brinjal (Solanum melongena L.). International Journal of Current Research. 3:038041.

5. Devi, S. A. and Mullainathan, L. 2012. Effect of Gamma Rays and Ethyl Methane Sulphonate (EMS) in M3 generation of Blackgram (Vigna mungo L. Hepper). African Journal of Biotechnology. 11: 35483552.

6. Tshilenge-Lukanda, L., Kalonji-Mbuyi, A., Nlongolo, K. K. C. and Kizungu, R. V. 2013. Effect of Gamma Irradiation on Morpho-Agronomic Characteristics of Ground nut (Arachis hypogea L.). American journal of Plant sciences. 4:2186-2192.

7. Arulbalachandran D, Mullainathan L, Velu S. Screening of mutants in black gram (Vigna mungo (L.) Hepper) with effect of DES and $\mathrm{COH}$ in $\mathrm{M} 2$ generation. Journal of Phytology. 2009;1(4):213-218.

8. Pelecanos M. and T. Alderson, 1964. The mutagenic activity of diethyl sulphate in Drosophila melanogaster. I. The dose-mutagenic response to larval and adult feeding. Mutation Res., 1:173-181.

9. Talebi, A. B., Talebi, A. B. and Shahrokhifar, B. 2012. Ethyl Methane Sulphonate (EMS) Induced Mutagenesis in Malaysian Rice (cv. MR219) for Lethal Dose Determination. American Journal of Plant Sciences. 3:1661-1665.

10. Pavadai P, Girija M, Dhanavel D. Effectiveness Efficiency and biochemical content of Physical and Chemical Mutagens in Soybean (Glycine max (L.) Merr.). Journal of phytology. 2009;1(6):444-447.
11. Gaul, H.1964. Mutation in plant breeding. Rad. Bot. 4: 155-232.

12. L. Mullainathan, K. Aviya. Studies on effect of induced mutagenesis on Finger millet (Eleusine coracana (L.) Gaertn.) Var-CO 13 in M1 generation. Horticultural Biotechnology Research, 2018;4:23-5.

13. Deepika, Minakshi pal and Pahuja, S. K. 2016. Morphological variations induced by Ethyl Methane Sulphonate in Cluster bean (Cyamopsis tetragonoloba (L.) Taub.). Forage Res. 41 : 218-221.

14. Kulkarni, G. B. 2011. Effect of mutagen on pollen fertility and other parameters in horsegram (Macrotyloma uniflorum (Lam.) Verdc). Bio. Sci. discovery. $2: 146-150$.

15. Joshi, N., Ravindran, A. and Mahajan, V. 2011. Investigation on Chemical Mutagen Sensitivity in Onion (Allium cepa L.). International Journal of Botany. 7: 243-248.

16. Roychowdhury, R., Ferdousul Alam, M. J., Bishnu, S., Dalal, T. and Tah, J. 2012. Comparative study for effects of Chemical Mutagenesis on Seed Germination, Survivability and Pollen Sterility in M1 and M2 generations of Dianthus. Plant Breeding and Seed Science. 65:29-38.

17. Bolbhat Sadashiv, N., BhogeVikra, D. and Dhumal Kondiram, N. 2012. Effect of mutagens on seed germination, plant survival and quantitative characters of Horsegram (Macrotyloma uniflorum (Lam.) Verdc). International journal of Life Science and Pharma Research. $2: 129-136$.

18. Bharathi, T., Gnanamurthy, S. and Dhanavel, D. 2013. Induced Physical mutagenesis on seed germination, lethal dosage and morphological mutants of Ashwagandha (Withania somnifera (L.) Dunal). International journal of Advanced Research. 1:136-141.

19. Ambli, K. and Mullainathan, L. 2015. Induced Physical and Chemical studies in M1 generation of Pearl Millet (Pennisetum typhoides) (Burn.) Stapf. Var. $\mathrm{Co}(\mathrm{Cu})$-9. International Journal of Recent Scientific Research. 5: 1806-1809.

20. Ramadoss, B. R., Ganesamurthy, K. and Angappan, K. 2014. Evaluation of Effect of Gamma rays on Sesame Genotype TTVS 51 and TTVS 19 in M1 Generation. International Journal of Development Research. 4: 273-277.

21. Baghery, M. A., Kazemitabar, S. K. and Kenari, R. E. 2016. Effect of EMS on germination and survival of Okra (Abelmoschus esculentus L.). Biharean biologist. 10: $33-36$. 